\title{
DIRECT EFFECT OF LMX ON OCB IN MALAYSIA
}

\author{
Junaidah Yusof*
}

Faculty of Social Sciences

Quest International University

Malaysia

\section{Hashim Fauzy Yaacob}

Faculty of Social Sciences and Humanities

Universiti Teknologi Malaysia

Malaysia

\author{
Siti Aisyah Abdul Rahman
}

Faculty of Social Sciences and Humanities

Universiti Teknologi Malaysia

Malaysia

\author{
Ang Kean Hua
}

Faculty of Science and Technology

Quest International University

Malaysia

\section{Noor Hafizah Abdul Halim}

Faculty of Science and Technology

Quest International University

Malaysia

\section{Noor Eleena Nordin}

Faculty of Social Sciences

Quest International University

Malaysia

*Corrosponding author's Email: junaidah.yusof@qiup.edu.my

Peer-review under responsibility of $3^{\text {rd }}$ Asia International Multidisciplanry Conference 2019 editorial board

(http://www.utm.my/asia/our-team/)

(C) 2019 Published by Readers Insight Publisher,

lat 306 Savoy Residencia, Block 3 F11/1,44000 Islamabad. Pakistan,

info@ readersinsight.net

This is an open access article under the CC BY-NC-ND license (http://creativecommons.org/licenses/by-nc-nd/4.0/). 


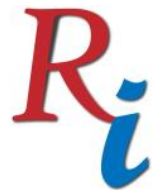

\section{Asia Proceedings of Social Sciences}

(APSS)

www.readersinsight.net/APSS

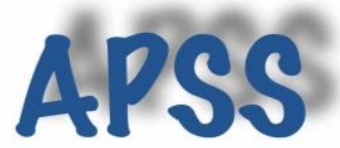

\section{Rese a r ch H i g h I igh t s}

This study investigates the antecedents of organisational citizenship behaviour (OCB) and its dimensions (i.e. altruism, courtesy, civic virtue, conscientiousness, and sportsmanship) among Malaysia Public Hospital nurses. The operational definition of leader-member exchange (LMX) in this study is the quality of the exchange relationship between the leader and the nurses which are developed based on perceived contribution and affect dimensions. An operational definition of OCB in this study is a personal choice of extra-role behaviour among Malaysia public hospital nurses U29. This behaviour is not stated in job description, it is discretionary, and not directly or explicitly recognised by the formal reward system, but it can promote the organisational effectiveness. OCB compromises five dimensions which are altruism, courtesy, civic virtue, conscientiousness, and sportsmanship.

\section{Graphical A bstract}

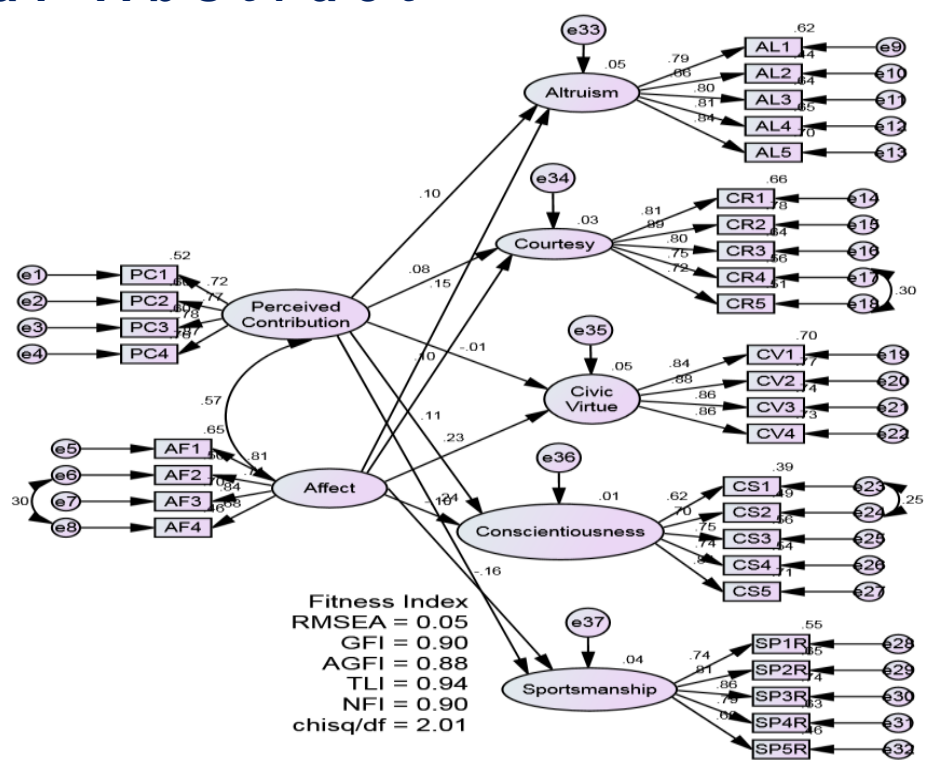

\section{Research Objectives}

The objectives of Wawasan 2020 have forced Malaysia organisations to confront unanticipated challenges. These challenges include changes in technological structure, shocks in economic trends, social changes, and structural transformations (Kim \& Hunsaker, 2018). Meeting all these challenges is indispensable for an organisation's survival but it has become a tough trade to do (Baek-Kyoo \& Sung, 2017; Chen \& Jin, 2014). One possible way to survive in this unpredictable situation is to make the best use of available resources such as organisational human resources (Baek-Kyoo and Sung, 2017; Bitmis and Ergeneli, 2011). It is believed that the practise of OCB among employees can enable an organisation to cope with these challenges (Bitmis \& Ergeneli, 2011; Chen \& Jin, 2014; Wu \& Lee, 2017). Considering all of the above statements, it is necessary to find out how to increase nurses' OCB in the workplace. Hence, this study was conducted to determine the direct effect of LMX on OCB as prior to the Social Exchange Theory. It is believed when subordinates have a high quality LMX, they will reciprocate the positive influence and perform OCB in the workplace. 
www.readersinsight.net/APSS

\section{Methodology}

The data collection in this study was conducted through distribution of questionnaires. Multistage cluster sampling is used in this study because it involves a wide area and large population size which makes it difficult or impossible to list the subjects. There are more than 133 public hospitals all over Malaysia. Applying multi-stage cluster sampling method is useful because the researchers have no access to the entire population and it is geographically convenient. Hence, this study managed to get 539 respondents from four selected government hospitals with the return rate about 35.5 percent. In this study, the researchers adapted the Leader-member Exchange Scale by Bhal and Ansari (Bhal \& Ansari, 1996, 2000) to measure LMX. While the Organisational Citizenship Behaviour Scale by Podsakoff et al. (1990) was adapted to measure OCB. Structural Equation Modelling is employed in this research as a statistical approach to measure the comparative strength of the indirect and direct relationship between the variables.

\section{Results}

The result indicated the model has yielded a good fit with RMSEA $=0.05$, GFI $=0.90$, AGFI $=0.88, \mathrm{CFI}=0.95, \mathrm{TLI}=0.94, \mathrm{NFI}=0.90$, and chisq $/ \mathrm{df}=2.01$. Overall, the perceived contribution and affect found to explain 5.1 percent of altruism occurrence, 2.6 percent of courtesy occurrence, 5 percent of civic virtue occurrence, 1 percent of conscientiousness occurrence, and 4 percent on sportsmanship occurrence among Malaysia public hospital nurses. Specifically, perceived contribution was found to significantly give an effect to only sportsmanship $(\beta=0.242, \mathrm{p}<0.001)$. That is, high quality of perceived contribution increases the occurrence of sportsmanship among nurses. However, perceived contribution has an insignificant effect on altruism, courtesy, civic virtue, and conscientiousness. The second dimension of LMX which is affect was found to significantly contribute to altruism ( $\beta$ $=0.153, \mathrm{p}<0.05)$, courtesy $(\beta=0.102, \mathrm{p}<0.05)$, civic virtue $(\beta=0.228, \mathrm{p}<0.001)$, and sportsmanship $(\beta=-0.164, \mathrm{p}<0.001)$. That is, high quality affect relationship between the leader and the subordinate increases the occurrence of altruism, courtesy, civic virtue, and sportsmanship among nurses. However, affect was found to have no significant contribution to conscientiousness.

\section{Findings}

This study expanded the Social Exchange Theory by providing empirical evidence on the association of LMX on OCB. From the empirical evidence, it was found out that high-quality of work-based relationship has a valid influence on sportsmanship. The findings also revealed high-quality of personal-based relationship between the leader and the subordinate has a significant positive influence on altruism, courtesy, and civic virtue, while the negative influence on sportsmanship. It is suggested that personal-based relationship between the leader and the subordinate needs to be practiced with precaution since high-level personal relationships could manifest the occurrence of negative effect towards sportsmanship.

\section{Acknowledgement}

We are grateful for the opportunity provided by Quest International University and Universiti Teknologi Malaysia to publish our research finding. 


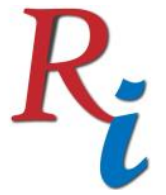

\section{Asia Proceedings of Social Sciences \\ (APSS) \\ www.readersinsight.net/APSS}

\section{References}

Baek-Kyoo, J., \& Sung, J. J. (2017). The effects of perceived authentic leadership and core self-evaluations on organizational citizenship behavior: The role of psychological empowerment as a partial mediator. Leadership \& Organization Development Journal, 38(3), 463-481.

Bhal, K. T., \& Ansari, M. A. (1996). Measuring quality of interaction between leaders and members. Journal of Applied Psychology, 26(11), 945-972.

Bhal, K. T., \& Ansari, M. A. (2000). Managing dyadic interaction in organizational leadership. New Delhi: Sage.

Bitmis, M. J., \& Ergeneli, A. (2011). Contigency approach to strategic management: A test of the mediating effect of leader-member exchange on the relationship between psychological empowerment and job satisfacion in 21st century workplace. Procedia Social and Behavioral Sciences, 24, 1143-1153.

Chen, H., \& Jin, Y.-H. (2014). The Effects of Organizational Justice on Organizational Citizenship Behavior in the Chinese Context: The Mediating Effects of Social Exchange Relationship. Public Personnel Management, 43(3), 301-313.

Kim, Y. J., \& Hunsaker, W. D. (2018). The effect of workplace spirituality on organizational citizenship behavior: The mediating effect of job engagement. The International Journal of Humanities \& Social Studies, 6(2), 67-74.

Podsakoff, N. P., MacKenzie, S. B., \& Moorman, R. H. (1990). Transformational Leader Behaviors and Their Effects on Followers' Trust in Leader, Satisfaction and Organizational Citizenship Behaviors. Leadership Quarterly, 1, 107-142.

Wu, W. L., \& Lee, Y. C. (2017). Empowering group leaders encourages knowlegde sharing: Integrating the social exhange theory and positive organizational behavior perspective. Journal of Knowledge Management, 21(2), 474-491. 